\title{
Article
}

\section{British Gynaecological Cancer Society recommendations and guidance on patient-initiated follow-up (PIFU)}

Newton, Claire, Nordin, Andy, Rolland, Philip, Ind, Thomas, LarsenDisney, Peter, Martin-Hirsch, Pierre, Beaver, Kinta, Bolton, Helen, Peevor, Richard, Fernandes, Andrea, Kew, Fiona, Sengupta, Partha, Miles, Tracie, Buckley, Lynn, Manderville, Helen, Gajjar, Ketan, Morrison, Jo, Ledermann, Jonathan, Frost, Jonathan, Lawrence, Alexandra, Sundar, Sudha and Fotopoulou, Christina

Available at https://clok.uclan.ac.uk/33173/

Newton, Claire, Nordin, Andy, Rolland, Philip, Ind, Thomas, Larsen-Disney, Peter, Martin-Hirsch, Pierre, Beaver, Kinta orcid iconORCID: 0000-0002-65522323, Bolton, Helen, Peevor, Richard et al (2020) British Gynaecological Cancer Society recommendations and guidance on patient-initiated follow-up (PIFU). International Journal Of Gynecological Cancer, 30 (5). pp. 695-700. ISSN 1048-891X

It is advisable to refer to the publisher's version if you intend to cite from the work. http://dx.doi.org/10.1136/ijgc-2019-001176

For more information about UCLan's research in this area go to http://www.uclan.ac.uk/researchgroups/ and search for < name of research Group>.

For information about Research generally at UCLan please go to

http://www.uclan.ac.uk/research/

All outputs in CLoK are protected by Intellectual Property Rights law, including Copyright law. Copyright, IPR and Moral Rights for the works on this site are retained by the individual authors and/or other copyright owners. Terms and conditions for use of this material are defined in the policies page. 


\section{ABSTRACT}

The National Cancer Survivorship Initiative through the National Health Service (NHS) improvement in the United Kingdom (UK) started the implementation of stratified pathways of patient-initiated follow-up (PIFU) across various tumour types. Now the initiative is continued through Living With and Beyond Cancer programme by NHS England.

Evidence from non-randomised studies and systematic reviews does not demonstrate a survival advantage to the long-established practice of hospital-based follow-up (FU) regimens, traditionally over 5 years. Evidence shows that patient needs are inadequately met under the traditional hospital-based follow-up FU-programmes and there is therefore an urgent need necessity to adapt pathways to the needs of patients. The assumption that hospital-based-hospital-based follow-upFU is able to detect cancer recurrences early and hence improve patients' prognosis has not been validated. A recent survey demonstrates that hospital-based follow-upFU practice across the UK varies widely, with telephone followupFU clinics, nurse-led clinics, and PIFU becoming increasingly common.

There are currently no completed randomised controlled trials in -PIFU in gGynaecological malignancies, although there is a drive towards implementing PIFUit. PIFU aims to individualise patient care, based on risk of recurrence and holistic needs, and optimising resources. The British Gynaecology Cancer Society (BGCS) wishes to provide the gynaecological oncology community with guidance and a recommendations' statement regarding the value, indications and limitations of PIFU in endometrial, cervical, ovarian and vulva cancers in an effort to standardise practice and improve patient care.

Key words: Patient initiated follow-up (PIFU), gGynaecology oOncology, follow-up (FU), gGynaecological malignancies.

Precis: British Gynaecology Cancer Society (BGCS) recommendations' statement regarding the value, indications and limitations of PIFU in endometrial, cervical, ovarian and vulvar carcinoma 
The British Gynaecology Cancer Society (BGCS) has issued a number of guidelines to improve the quality of care and standardise treatment and follow-up pathways for patients with gynaecological cancer. As the practice of follow up varies widely and is continuously evolving, the BGCS wished to implement strategies for a UK-wide implementation of patient initiated follow-up (PIFU), addressing its indications, value and limitations across all different gynaecological cancer sites. The National Cancer Survivorship Initiative, through NHS improvement, has already implemented stratified pathways (including some patient initiated) for follow up in breast, colorectal ${ }_{2}$ and prostate cancer ${ }^{2}$. Patients with early stage cancer of breast, colorectal and prostate may be offered remote surveillance and at the present time no surveillance techniques have been deemed to be effective in gynaecological cancers.

Historically, patients have been kept on hospital-based follow up in dedicated outpatient clinics for 5-10 years following diagnosis and treatment for gynaecological cancer $\frac{3,4}{4}$ The main aims of follow-up include: detection of asymptomatic recurrences, with the assumption that this will improve prognosis; detection and management of side effects of treatment; improvement in quality of life; identification and treatment of patient concerns and anxieties around their cancer diagnosis $\frac{5,6}{}$. However, there is no evidence that intensive follow-up improves survival ${ }^{7-13}$ and women often find clinical examination uncomfortable (especially vaginal examination) with 54\% (48/89) experiencing increased anxiety prior to their follow up appointments $\underline{s}^{6}$.

There is evidence that the current hospital-based follow-up does not necessarily meet cancer survivors needs, failing to provide emotional support and information needs $\underline{14}$ due to limited time, resources and lack of focus on a holistic approach of the patients' needs. A holistic approach will take account of mental and social factors as well as symptoms of the disease. In 2010 the National Cancer Survivorship Initiative (NCSI) was launched by the Department Of Health in England in collaboration with one of the UK's largest charitable organisations, Macmillan Cancer Support, to improve the long term consequences of surviving cancer $\stackrel{15}{ }$. In more recent years, the Living With and Beyond Cancer programme ${ }_{\text {_ }}^{16}$ has advocated a shift in care and support towards selfmanagement, based on individual needs and preferences, and away from the traditional single model of clinical follow-up. This approach empowers individuals to take responsibility 
for their condition, supported by clinical assessment to enable early recognition of symptoms of recurrence or consequences of their treatment and a 'Recovery Package' that includes holistic needs assessments (performed after completion of treatment for cancer), treatment summaries, health and well-being events and cancer care reviews in primary care ${ }^{16}$.

There are different follow up methods currently utilised in the UK which include hospital follow up, telephone follow up and PIFU. Hospital follow up involves seeing patients in clinics at regular intervals, whereas telephone follow up involves calling patients at a specified time at pre-determined intervals. PIFU involves educating patients about concerning symptoms, such as vaginal bleeding, unintentional weight loss, and worsening abdominal pain or bowel/bladder symptoms. In patient-initiated follow up, patients are not given routine follow up appointments (hospital, telephone or with the General practitioner), but instead are empowered to call the gynaecological oncology team directly (often via the clinical nurse specialist with specialist cancer knowledge) if they have these symptoms and then they are fast-tracked back into the specialist care system. It is very important that patients are given written information about PIFU, which includes the contact details should they need them. Most patients find PIFU acceptable $\frac{17}{}$, although younger patients and those who struggle to access healthcare (due to socio-demographic factors) may require the additional support ${ }^{18}$ of routine contact, either via hospital follow up or telephone follow up.

\section{METHODS}

The BGCS PIFU meeting was held on $14^{\text {th }}$ March 2019 in London, UK. Experts from clinical practice (including medicine and nursing) and academia with specialist knowledge and expertise in gynaecology oncology and alternative follow up strategies reviewed available evidence from a systematic literature search in Medline, Embase CINAHL, AMED, BNI, HBE, HMIC, PsycINFO that aimed to identify significant evidence on alternatives to hospital-based follow-up. These data were presented, discussed and evaluated by the key opinion leaders. Additionally, data from a national survey of follow-up practice across the UK in gynaecological malignancies were presented. All experts agreed the consensus 


\begin{tabular}{|l|}
\hline General eligibility criteria for PIFU \\
\hline Completed primary treatment for a gGynaecological malignancy and are clinically well \\
\hline Patients should be willing and able to access healthcare if on PIFU \\
\hline They should be without significant treatment related side-effects that need ongoing management \\
\hline They should not have recurrent disease \\
\hline They should not be on active or maintenance treatment \\
\hline $\begin{array}{l}\text { They should not be on a clinical trial where follow-up schemes are defined and limited to hospital- } \\
\text { based follow upFU }\end{array}$ \\
\hline $\begin{array}{l}\text { They should not have a rare tumour with uncertain risk of recurrence and need for ongoing } \\
\text { management } \\
\text { They must be able to communicate their concerns without a significant language barrier or } \\
\text { psychological comorbidity and have competence to agree to PIFU }\end{array}$ \\
\hline
\end{tabular}

guidelines for each gynaecological tumour site (cervical, ovarian, endometrial and vulva).

Although there was no patient representative at the BGCS PIFU meeting, there has been positive feedback from patients within the hospitals that have already implemented the guidelines and in studies that looked at patient acceptability ${ }^{17-19}$

\section{DISCLAIMER}

Clinicians should always use their clinical judgement to determine if an individual patient is suitable for PIFU. These consensus recommendations have been produced as guidance for follow up pathways and are based on available evidence. Where little evidence existed, expert consensus was agreed.

\section{RESULTS}

PIFU guidance for each cancer type will be presented separately under the general umbrella and recommendation that only those patients who fit all of the criteria below are eligible and safe to be offered PIFU: 
106

At the clinic visit prior to offering PIFU, patients should be provided with a careful explanation on the lack of evidence for benefit from regular follow-up visits to the hospital and the rationale for implementing a supported self-management approach (PIFU). However, for patients with significant iatrogenic side effects, which impair their quality of life and need active management, it is important that those are addressed and managed within in the clinic setting with sufficient access to other health professionals, such as gastroenterologists, urologists, endocrinologists, and psychologists. PIFU should be offered on a case-by-case basis, ensuring there are no existing unmet needs and according to their cancer type.

\section{ENDOMETRIAL CANCER}

There are approximately 9,300 new cases of endometrial cancer in the UK and it is the $4^{\text {th }}$ most common cancer in women $\underline{20}$. There has been an increase of nearly $20 \%$ in the last 10 years $^{20}$, which is thought to be largely due to the sharp increase in obesity, although rarer tumours, not associated with obesity have also increased.

Low risk endometrial cancer is defined by the (European Society of Medical OncologyEuropean Society of Gynecological Oncology) ESMO-ESGO guidelines 21 as stage ! endometrioid, grade 1-2 histology, with $\leq 50 \%$ myometrial invasion, negative for lymphovascular space invasion and hence not in need of adjuvant treatment $\underline{\underline{21}}$. Following hysterectomy and bilateral salpingo-oophorectomy, patients have their holistic needs assessment and the next steps of their journey discussed with their dedicated cancer support workers, under the coordination and guidance of the clinical nurse specialists. They can also be referred to psycho-oncological counselling services, if required and accepted by the patient. Patients are educated about symptoms that would be concerning for a recurrence, such as vaginal bleeding, worsening or persistent abdominal pain, or bladder/bowel symptoms. A population study by Salvesen over 10 years demonstrated that 653 patient consultations were needed to pick up one asymptomatic low risk endometrial cancer patient with recurrent disease ${ }_{12,13}$. Based on a very low risk of relapse without adjuvant treatment, these patients could be offered PIFU after they have

Commented [M5]: Please note that neither of these references is the reference by Salvensen

Please adjust accordingly

Commented [NC6]: Apologies, I have changed it as its reference 12 and 13 
completed treatment at, or shortly after, the time of their holistic needs assessment appointment (Figure 1).

Intermediate risk endometrial cancer is defined by the ESMO-ESGO guidelines ${ }^{21}$ as stage I endometrioid, grade 1-2, $\geq 50 \%$ myometrial invasion, lymphovascular space invasion negative. These patients are commonly offered vaginal brachytherapy, without external beam radiotherapy, following their hysterectomy $\underline{\underline{21}}$. Their risk of recurrence is relatively low. Patients could be offered PIFU at the 3-month review after treatment or anytime during the first 2 years of hospital follow up. It is important for patients to be aware that they may develop late onset toxicity following brachytherapy that may not be apparent shortly after finishing their treatment. For that reason, it should be explained that they can be seen back in clinic, if their have concerns related to toxicity, as well as if they have symptoms concerning for recurrence, if they are on PIFU. Another option for these patients is telephone follow up with - randomised controlled trial level data of no physical or psychological detriment, compared to hospital follow-up, in stage I endometrial cancer $\underline{22}$ Telephone follow-up could be seen as a useful transition between face to face hospitalbased appointments and PIFU.

High-intermediate risk endometrial cancer is defined by the ESMO-ESGO guidelines ${ }_{-}^{21}$ as patients with grade $1-2$ tumours with deep $(\geq 50 \%)$ myometrial invasion and unequivocally positive (substantial, not focal) lymphovascular space invasion, and those with grade 3 tumours with $<50 \%$ myometrial invasion regardless of lymphovascular space invasion status. These patients are treated as high risk for the purpose of these guidelines, due to their higher risk of recurrent disease. High-intermediate risk endometrial cancer represents a heterogeneous group of patients, including both endometrioid and non-endometrioid tumour types, such as serous and clear cell, and ranges from stage IB grade 3 (with or without lymphovascular space invasion and with or without nodal staging) to more advanced FIGO stages ${ }^{21}$. The risk of recurrence is higher for these patients (>20\%) and therefore it is suggested that they should be seen in the clinic for at least the first 2 years, as this is the most frequent time for recurrence ${ }^{23,24}$. After 2 years patients could be offered PIFU for the remaining 3 years (Figure 1). Again, another alternative is telephone follow upfor the remaining 3 years. 


\section{CERVICAL CANCER}

There are approximately 3,200 new cases of cervical cancer every year_with an incidence of 12 per 100,000 in the UK $\underline{25}$.

In patients with a FIGO stage IA 1 cervical cancer the British Society of Colposcopy and Cervical Pathology (BSCCP) recommend cervical cytology should be taken 6 and 12 months after treatment (hysterectomy or LLETZ) followed by annual cytology for a further 9 years before returning to routine recall until the age of 65 for those treated with LLETZ and still have a cervix ${ }^{27}$. If patients have had a hysterectomy for stage $\underline{I A} 1$ cervical cancer there are specific guidelines on cytology follow-up depending on histology of the hysterectomy specimen ${ }^{27}$. Patients who have had a hysterectomy for stage $\underline{I A} 1$ are also excluded from PIFU.

In low risk patients (FIGO stage IB 1 ) who have undergone a radical hysterectomy for treatment of cervical cancer the BGCS recommends follow-up in the clinic setting every 3-4 months in the first 2 years, and then PIFU can be offered (Figure 2). It should be noted that the BSCCP recommends vault smears at 6 and 18 months after a hysterectomy for cervical intraepithelial neoplasia $(\mathrm{CIN})^{27}$ if margins are free of $\mathrm{CIN}$. However, vaginal vault cytology should not be performed following treatment for FIGO stage $\geq$ IA 2 as it does not add significantly to the detection of recurrent disease $\frac{25,27-28}{}$. These patients have a 5-year risk of recurrence of 5.8-8\% $27,29-31$. However only $4-5 \%$ will have pelvic recurrences and only $1-2 \%$ can be salvaged $28,31,32$, although this has increased slightly with cyberknife and other techniques. In a large Danish national cohort study of 1523 patients with low-risk cervical cancer, of those with recurrent disease, $67.5 \%$ experienced a symptomatic recurrence ${ }_{-}^{30}$ Other studies have shown similar rates of symptomatic recurrent cervical cancer $\stackrel{24}{ }$. Therefore, as the majority present with symptoms, PIFU appears to be reasonable for low-risk patients. As surgery for early stage cervical cancer may cause morbidity, such as bladder dysfunction and lymphoedema, hospital follow up for the first 2 years was thought to be preferable to telephone follow up (BGCS consensus agreement).

In patients with intermediate (risk of recurrence 10-20\%) or high risk (risk of recurrence $>20 \%$ ) disease, hospital follow up, to include taking an appropriate history and clinical 
examination at each visit, should be undertaken to try and detect recurrent disease. This group of patients usually have FIGO stage $\geq \underline{\mathrm{B}} 2_{2}$ although there are other factors that play a role in the likelihood of recurrence, such as lymph node status and lymphovascular space invasion $^{30}$. Hospital follow up should be undertaken for 5 years, particularly as these patients may have significant treatment-related toxicity (Figure 2). However, it should be noted that the majority of recurrences occur within 2 years; a Norwegian national prospective observational study by Vistad et al. in 2017, which included 680 patients with gynaecological cancer recurrence, showed a mean annual incidence rate from years 3-5 of only $<7 \%$ 을.

\section{OVARIAN CANCER}

There were 7,500 women who developed tubo-ovarian/primary peritoneal cancer in the UK in 2016 making it the $6^{\text {th }}$ most common cancer in women ${ }^{34}$. The majority of those who developed tubo-ovarian/primary peritoneal cancer had epithelial ovarian cancer, which relates to these guidelines. Non-epithelial ovarian cancers, such as granulosa cell tumours or germ cell tumours of the ovary, are not included in these guidelines, as they have their own distinct pathogenesis and behave differently from epithelial ovarian cancer. Fertility-preserving surgery, that includes a unilateral salpingo-oophorectomy and full surgical staging, is acceptable in young patients with stage IA (grade 1 and 2), and stage IC (grade 1) disease, as they have similar recurrence rates and overall survival to those undergoing conventional treatment $\frac{35}{}$. However, these patients should be seen regularly for hospital follow up and ultrasound scans of the contralateral ovary and are excluded from PIFU.

Only patients who have been adequately staged, with pelvic and para-aortic lymphadenectomy and peritoneal biopsies for an apparent stage I ovarian cancer, should be offered PIFU, so that occult higher stage cancers with higher risk of relapse, are not included $\underline{36}$. Patients with fully staged $\underline{I A} / \underline{B}$ ovarian cancer (of any grade) have a low risk of recurrence and therefore could be offered PIFU after they have completed their treatment (Figure 3). Evidence does not suggest that routine follow-up of patients with ovarian cancer improves survival $\frac{37-40}{2}$. A randomised phase III study OV05-EORTC $55955^{40}$, which compared initiation of chemotherapy on development of elevated 
CA125 versus initiation of chemotherapy on clinical/symptomatic evidence of relapse showed treatment was delayed by a median of 4.8 months in the latter group with no detriment to overall survival (HR 1.01; 95\% Cl 0.82-1.25; $\mathrm{P}=0.91)$. Moreover, quality of life was lower in the patients that had initiation of chemotherapy on CA125 rise. However, this study took place outside the possibility of secondary cytoreductive surgery for recurrent ovarian cancer and also before the establishment of targeted and maintenance agents at relapsed disease and it is unclear whether we can translate its findings to the modern era of ovarian cancer management $\underline{36,42}$.

At the follow-up appointment, symptoms should be assessed and a physical examination should be carried out in the first 3 years from completing treatment in patients with FIGO stage $2-4$, as this is the most common time period in which recurrent disease develops $\underline{30}$ . In years 4 and 5 , in the absence of recurrent disease, patients could have the option of moving to a combination of telephone follow up with CA125 serial measurements, if deemed suitable by their clinician. There is evidence that telephone follow up in ovarian cancer is well received and the majority preferred it to hospital follow up ${ }^{43}$. If patients are not suitable for telephone follow up and remote CA125 measurements, patients should continue hospital follow up for a minimum of 5 years after completing treatment.

\section{VULVAR CANCER}

Vulvar cancer is rare with only 1,300 new cases in 2015 in the UK, which is less than $1 \%$ of all

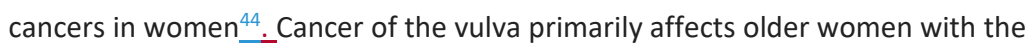

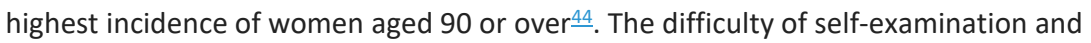
the increased numbers of cases in deprived areas ${ }_{44}$ leads to a greater number of vulnerable women. Therefore, the BGCS recommends that women with vulvar cancer are not suitable for PIFU (Figure 4) and should follow the traditional follow up schemes involving careful clinical examination. This should be performed by clinicians with appropriate experience, which would usually be in the hospital setting.

There is no evidence for the recommendations of frequency of examinations. The ESGO expert consensus guidelines and RCOG guidelines on vulvar cancer ${ }^{45}$ recommend 3-4 monthly follow-up in the first 2 years, biannually for years 3 and 4 and then annual life-long 
follow-up. This is supported by a retrospective analysis of 330 patients with primary vulvar carcinoma treated at the Mayo clinic, which showed 35\% of recurrences occurred more

than 5 years after diagnosis with both distant and local disease ${ }^{46}$. The BGCS

recommends follow up of patients with vulval cancer for at least 5 years, with longer

follow-up at the discretion of the treating clinician. Patients with multi-focal vulvar intraepithelial neoplasia (VIN) or lichen sclerosis with VIN (differentitated VIN) are at high risk of multi-focal disease and more intensive follow-up may be warranted $\frac{45,47}{}$.

\section{ACKNOWLEDGMENTS}

We would like to thank Debbie Lewis for her help in organising the BGCS PIFU meeting.

\section{COMPETING INTERESTS}

None

ETHICS

No ethical review was necessary as this is a review article and therefore we did not use any human participants for this piece of research.

\section{FUNDING}

All costs relating to the BGCS guideline meeting on patien- initiated follow-up were covered by BGCS funds.
Commented [M10]: Here, do you mean annually? Please specify

Commented [NC11]: Yes. I have added in 'annual' 


\begin{tabular}{|c|c|c|c|}
\hline Endometrial Cancer & Clinic-based FU & $\begin{array}{l}\text { Telephone FU } \\
+/ \text { - blood test }\end{array}$ & PIFU \\
\hline $\begin{array}{l}\text { Low risk } \\
\text { (<10\% risk of } \\
\text { recurrence } R O R \text { ) }\end{array}$ & $\begin{array}{l}\text { If patient } \\
\text { declines PIFU } \\
\text { (for maximum } \\
\text { of } 2 \text { years from } \\
\text { end of } \\
\text { treatment) }\end{array}$ & $\begin{array}{l}\text { If patient } \\
\text { declines PIFU } \\
\text { (for maximum } \\
\text { of } 2 \text { years from } \\
\text { end of } \\
\text { treatment) }\end{array}$ & $\begin{array}{l}\text { Offer from end of } \\
\text { treatment (after } \\
\text { Holistic needs } \\
\text { assessment at } 3 \\
\text { months) }\end{array}$ \\
\hline Intermediate risk & $\begin{array}{l}\text { Can be offered } \\
\text { if declines PIFU } \\
\text { for } 2 \text { years from } \\
\text { end of } \\
\text { treatment }\end{array}$ & $\begin{array}{l}\text { Can be offered } \\
\text { if declines PIFU } \\
\text { for } 2 \text { years from } \\
\text { end of } \\
\text { treatment }\end{array}$ & $\begin{array}{l}\text { offer from end of } \\
\text { treatment or } \\
\text { after } 2 \text { years for } \\
\text { all }\end{array}$ \\
\hline High -intermediate risk & $\begin{array}{l}\text { For } 5 \text { years } \\
\text { (either } \\
\text { telephone FU or } \\
\text { clinic FU) }\end{array}$ & $\begin{array}{l}\text { For } 5 \text { years } \\
\text { (either } \\
\text { telephone FU or } \\
\text { clinic FU) }\end{array}$ & $\begin{array}{l}\text { offer from } 2 \text { years } \\
\text { from end of } \\
\text { treatment in } \\
\text { place of } \\
\text { telephone FU or } \\
\text { clinic FU. }\end{array}$ \\
\hline High-risk & $\begin{array}{l}\text { For } 5 \text { years } \\
\text { (either } \\
\text { telephone FU or } \\
\text { clinic FU) }\end{array}$ & $\begin{array}{l}\text { For } 5 \text { years } \\
\text { (either } \\
\text { telephone FU or } \\
\text { clinic FU) }\end{array}$ & $\begin{array}{l}\text { offer from } 2 \text { years } \\
\text { from end of } \\
\text { treatment in } \\
\text { place of } \\
\text { telephone FU or } \\
\text { clinic FU. }\end{array}$ \\
\hline
\end{tabular}

Figure 1: Guidelines for follow-up in eEEndometrial cancer (ROR=risk of recurrence, PIFU= patient initiated follow-up, FU=follow-up) 


\begin{tabular}{|l|l|l|l|}
\hline Cervical Cancer & Clinic-based FU & $\begin{array}{l}\text { Telephone FU +/- } \\
\text { blood test }\end{array}$ & PIFU \\
\hline $\begin{array}{l}\text { Low risk (<10\% risk } \\
\text { of recurrence }\end{array}$ & $\begin{array}{l}\text { For } 5 \text { years post } \\
\text { completion of } \\
\text { fertility sparing }\end{array}$ & Not suitable & $\begin{array}{l}\text { Offer from 2 years } \\
\text { from end of }\end{array}$ \\
surgery/ LLETZ & treatment & Not suitable \\
\hline Intermediate risk & For 5 years post & Not suitable & \\
\hline completion of & & Not suitable \\
\hline treatment & For 5 years post & Not suitable & \\
\hline
\end{tabular}

282

Figure 2: Guidelines for follow-up in çGervical cancer (ROR=risk of recurrence, $\mathrm{PIFU}=$ patient initiated follow-up, LLETZ= large loop excision of transformation zone, FU=follow-up).) 


\begin{tabular}{|c|c|c|c|}
\hline Ovarian Cancer & Clinic-based FU & $\begin{array}{l}\text { Telephone FU +/- } \\
\text { blood test }\end{array}$ & PIFU \\
\hline $\begin{array}{l}\text { Low risk (<10\% risk of } \\
\text { recurrence ROR, stage } \\
\text { 1a/b fully staged) from } \\
\text { end of treatment } \\
\text { (surgery +/-chemo). } \\
\text { Excluding fertility } \\
\text { sparing surgery }\end{array}$ & $\begin{array}{l}\text { Can be offered } \\
\text { if declines PIFU } \\
\text { for } 2 \text { years from } \\
\text { end of } \\
\text { treatment }\end{array}$ & $\begin{array}{l}\text { Can be offered if } \\
\text { declines PIFU for } 2 \\
\text { years from end of } \\
\text { treatment }\end{array}$ & $\begin{array}{l}\text { Offer from end } \\
\text { of treatment } \\
\text { (after Holistic } \\
\text { needs } \\
\text { assessment at } \\
3 \text { months) }\end{array}$ \\
\hline FiGO stages $1 \mathrm{c}-4$ & $\begin{array}{l}\text { For } 3 \text { years } \\
\text { from end of } \\
\text { treatment }\end{array}$ & $\begin{array}{l}\text { Can be offered for } \\
\text { years } 4+5 \text { from end } \\
\text { of treatment }\end{array}$ & Not suitable \\
\hline
\end{tabular}




\begin{tabular}{|l|l|}
\hline Options for follow-up & Vulval Cancer \\
\hline PIFU for 5 years from treatment & Not suitable \\
\hline Remote/telephone +/- bloods & Not suitable \\
\hline Clinic-based FU & $\begin{array}{l}\text { Follow-up including clinical inspection } \\
\text { for at least } 5 \text { years from from end of } \\
\text { treatment }\end{array}$ \\
\hline
\end{tabular}

292

Figure 4: Guidelines for follow-up in v

(FU=follow-up, PIFU= patient initiated follow-up) 


\section{REFERENCES}

1. Leeson S, Stuart N, Sylvestre Y, Hall L, Whitaker R. Gynaecological cancer follow-up: national survey of current practice in the UK. BMJ Open 2013 Jul 24;3(7). pii: e002859. doi: 10.1136/bmjopen-2013-002859.

2. Watson E, Rose P, Hulbert-williams N, Donnelly P, Hubbard G, Elliot J, Campbell C, Wellers D, Wilkinson C. Personalised cancer follow-up: risk stratification, needs assessment or both? British Journal of Cancer 2012;106:1-5

3. Kew FM, Cruickshank DJ. Routine follow-up after treatment for a gynaecological cancer: a survey of practice. Int J Gynecol Cancer 2006;16:380-4.

4. https://www.bgcs.org.uk/wp-content/uploads/2019/08/BGCS-patient-initiatedfollowup-consensus-outcomes-sumary-final.vs3587.pdf. Accessed December 2019.

5. Kerr-Wilson RH, McCrum A. Follow-up of patients with gynaecological cancer. Aust NZ J Obstet Gynaecol 1995;35:298-9.

6. Kew FM, Galaal K, Manderville H, et al. Professionals' and patients'views of routine follow-up: a questionnaire survey. Int J Gynecol Cancer 2007;17:557-60.

7. Agboola O, Grunfeld E, Coyle D, et al. Costs and benefits of routine follow-up after curative treatment for endometrial cancer. Can Med Assoc J 1997;157:879-86.

8. Allsop JR, Preston J, Crocker S. Is there any value in the long-term follow-up of women treated for endometrial cancer? Br J Obstet Gynaecol 1997;104:122.

9. Gadducci A, Cosio S, Fanucchi A, et al. An intensive follow-up does not change survival of patients with clinical stage I endometrial cancer. Anticancer Res 2000;20:1977-84.

10. Owen $P$, Duncan ID. Is there any value in the long-term follow-up of women treated for endometrial cancer? Br J Obstet Gynecol 1996;103:710-13.

11. Reddoch JM, Burke TW, Morris M, et al. Surveillance for recurrent endometrial carcinoma: development of a follow-up scheme. Gynecol Oncol 1995;59:221-5.

12. Salvesen HB, Akslen LA, Iversen $T$, et al. Recurrence of endometrial carcinoma and the value of follow-up. Br J Obstet Gynaecol 1997;104:1302-7.

13. Fung-Kee-Fung, M., Dodge, J., Elit, L., Lukka, H., Chambers, A., Oliver, T. Follow-up after primary therapy for endometrial cancer: a systematic review. Gynecologic Oncology 2006;101:520-529. 
14. Sperling C, Sandager M, Jensen H, Knudsen JL. Current organisation of follow-up does not meet cancer patients' needs. Dan Med J 2014;61(6):A4855

15. Department of Health 2011. Improving outcomes: a strategy for cancer . http://www.dh.gov.uk/en/Publicationsandstatistics/Publications/PublicationsPolicyA ndGuidance/DH_123371. Accessed December 2019.

16. Living with and beyond cancer 2013.

https://www.gov.uk/government/publications/living-with-and-beyond-cancertaking-action-to-improve-outcomes. Accessed December 2019.

17. Beaver $\mathrm{K}^{1}$, Martin-Hirsch $\mathrm{P}^{2}$, Williamson $\mathrm{S}^{3}$, Kyrgiou $\mathrm{M}^{4}$ Exploring the acceptability and feasibility of patient-initiated follow-up for women treated for stage I endometrial cancer. Eur J Oncol Nurs. 2019 Nov 28;44:101704. doi: 10.1016/j.ejon.2019.101704.

18. Kumarakulasingam $\mathrm{P}^{1}, \mathrm{McDermott} \mathrm{H}^{2}$, Patel $\mathrm{N}^{3}$, Boutler $\mathrm{L}^{3}$, Tincello $\mathrm{DG}^{4}$, Peel $\mathrm{D}^{3}$, Moss EL ${ }^{1}$ Acceptability and utilisation of patient-initiated follow-up for endometrial cancer amongst women from diverse ethnic and social backgrounds: A mixed methods study. Eur J Cancer Care (Engl). 2019 Mar;28(2):e12997. doi: 10.1111/ecc.12997. Epub 2019 Feb 12

19. Jeppesen $\mathrm{MM}^{1,2}$, Jensen $\mathrm{PT}^{1,2}$, Hansen $\mathrm{DG}^{3}$, Christensen $\mathrm{RD}^{4}$, Mogensen $\mathrm{O}^{2}$ Patientinitiated follow up affects fear of recurrence and healthcare use: a randomised trial in early-stage endometrial cancer. BJOG. 2018 Dec;125(13):1705-1714. doi: 10.1111/1471-0528.15396

20. https://www.cancerresearchuk.org/health-professional/cancer-statistics/statisticsby-cancer-type/uterine-cancer\#heading-Zero. Accessed December 2019

21. Colombo N, Creutzberg C, Amant F, et al. ESMO-ESGO-ESTRO consensus conference on endometrial cancer: diagnosis, treatment and follow-up. Radiother Oncol 2015; 117: 559-81.

22. Beaver $\mathrm{K}^{1}$, Williamson $\mathrm{S}^{1}$, Sutton $\mathrm{C}^{2}$, Hollingworth $\mathrm{W}^{3}$, Gardner $\mathrm{A}^{4}$, Allton $\mathrm{B}^{5}$, AbdelAty $\mathrm{M}^{6}$, Blackwood $\mathrm{K}^{7}$, Burns $\mathrm{S}^{7}$, Curwen $\mathrm{D}^{8}$, Ghani $\mathrm{R}^{5}$, Keating $\mathrm{P}^{9}$, Murray $\mathrm{S}^{9}$, Tomlinson $\mathrm{A}^{10}$, Walker $\mathrm{B}^{6}$, Willett $\mathrm{M}^{6}$, Wood $\mathrm{N}^{9}$, Martin-Hirsch $\mathrm{P}^{9}$. Comparing hospital 
and telephone follow-up for patients treated for stage-I endometrialcancer (ENDCAT trial): a randomised, multicentre, non-inferiority trial. BJOG 2017 124(1):150-160. doi: 10.1111/1471-0528.14000. Epub 2016 Apr 7.

23. de Boer S, Melanie E Powell, Linda Mileshkin, Dionyssios Katsaros, Paul Bessette, Christine Haie-Meder, Petronella B Ottevanger,Jonathan A Ledermann, Pearly Khaw, Romerai D’Amico, Anthony Fyles, Marie-Helene Baron, Ina M Jürgenliemk-Schulz, Henry C Kitchener, Hans W Nijman, Godfrey Wilson, Susan Brooks, Sergio Gribaudo, Diane Provencher, Chantal Hanzen, Roy F Kruitwagen, Vincent T H B M Smit, Naveena Singh, Viet Do, Andrea Lissoni, Remi A Nout, Amanda Feeney, Karen W Verhoeven-Adema, Hein Putter, Carien L Creutzberg, on behalf of the PORTEC Study Group* Adjuvant chemoradiotherapy versus radiotherapy alone in women with high-risk endometrial cancer (PORTEC-3): patterns of recurrence and post-hoc survival analysis of a randomised phase 3 trial. Lancet Oncol 2019; 20: 1273-85

24. Vistad $I^{1}$, Bjørge $L^{2,3,4}$, Solheim $O^{5}$, Fiane $B^{6}$, Sachse $K^{7}$, Tjugum $\mathrm{J}^{8}$, Skrøppa $S^{9}$, Bentzen $A G^{10}$, Stokstad $T^{11}$, Iversen $G^{2}$, Salvesen $H^{2}{ }^{2}$, Kristensen $G B^{5,12}, D \varnothing r u m A^{5} A$ national, prospective observational study of first recurrence after primary treatment for gynecological cancer in Norway. Acta Obstet Gynecol Scand. 2017 Oct;96(10):11621169. doi: 10.1111/aogs.13199

25. https://www.cancerresearchuk.org/health-professional/cancer-statistics/statisticsby-cancer-type/cervical-cancer Accessed December 2019

26. Colposcopy and programme management. NHCSP publication 20, Public health England. Third edition 2016

27. Cibula $D^{1}$, Pötter $R^{2}$, Planchamp $F^{3}$, Avall-Lundqvist $E^{4}$, Fischerova $D^{5}$, Haie-Meder $C^{6}$, Köhler $\mathrm{C}^{7}$, Landoni $\mathrm{F}^{8}$, Lax $\mathrm{S}^{9}$, Lindegaard JC ${ }^{10}$, Mahantshetty $\mathrm{U}^{11}$, Mathevet $\mathrm{P}^{12}$, McCluggage $W^{13}{ }^{13}$ McCormack $M^{14}$, Naik $R^{15}$, Nout $R^{16}$, Pignata $S^{17}$, Ponce $J^{18}$, Querleu $\mathrm{D}^{3}$, Raspagliesi $\mathrm{F}^{19}$, Rodolakis $\mathrm{A}^{20}$, Tamussino $\mathrm{K}^{21}$, Wimberger $\mathrm{P}^{22}$, Raspollini $M R^{23}$ The European Society of Gynaecological Oncology/European Society for Radiotherapy and Oncology/European Society of Pathology Guidelines for the Management of Patients with Cervical Cancer. Virchows Arch 2018 Jun;472(6):919936. doi: 10.1007/s00428-018-2362-9. Epub 2018 May.

28. Caleia A, Pires C, Pereira J, Pinto-Ribeiro F, Longatto-filo A. Self sampling as a plausible alternative to sceen cervical cancer precursor lesions in a population with 
low attendance for screening: a systematic review. Acta Cytol. 2020 Jan 20:1-12. doi: 10.1159/000505121.

29. Elit L, Fyles A, Devries M, Oliver T, Michael Fung-Kee-Fung and The Gynecology Cancer Disease Site Group. Follow-up for women after treatment for cervical cancer: A systematic review. Gynaecol Oncol. 2009 Sep;114(3):528-35. doi: 10.1016/j.ygyno.2009.06.001. Epub 2009 Jun 26.

30. Taarnhøj G, Christensen J, Lajer H, Fuglsang K, Jeppesen M M, Strøm K, Høgdall C. Risk of recurrence, prognosis, and follow-up for Danish women with cervical cancer in 2005-2013: A national cohort study. Cancer. 2018 Mar 1;124(5):943-951. doi: 10.1002/cncr.31165. Epub 2017 Dec 6.

31. Srisomboon J, Kietpeerakool C, Suprasert P, et al. Survival and prognostic factors comparing stage IB 1 versus stage IB 2 cervical cancer treated with primary radical hysterectomy. Asian Pac J Cancer Prev. 2011;12:1753-1756.

32. Friedlander M, Grogan M. Guidelines for the treatment of recurrent and metastatic cervical cancer. Oncologist. 2002;7:342-347.

33. Mabuchi S, Isohashi F, Yoshioka Y, et al. Prognostic factors for survival in patients with recurrent cervical cancer previously treated with radiotherapy. Int J Gynecol Cancer. 2010;20:834-840.

34. https://www.cancerresearchuk.org/health-professional/cancer-statistics/statisticsby-cancer-type/ovarian-cancer. Accessed December 2019.

35. Bentivegna E, Gouy S, Maulard A et al. Fertility-sparing surgery in epithelial ovarian cancer: a systematic review of oncological issues. Ann Oncol 2016; 27(11): 19942004.

36. Colombo, C. Sessa, A. du Bois, J. Ledermann, W. G. McCluggage, I. McNeish, P. Morice, S. Pignata, I. Ray-Coquard, I. Vergote, T. Baert, I. Belaroussi, A. Dashora, S. Olbrecht, F. Planchamp \& D. Querleu. ESMO-ESGO Consensus Conference Recommendations on Ovarian Cancer: Pathology and Molecular Biology, Early and Advanced Stages, Borderline Tumours and Recurrent Disease. Ann Oncol 2019; 30: 672-705.

37. Clarke T, Galaal K, Bryant A, Naik R. Evaluation of follow-up strategies for patients with epithelial ovarian cancer following completion of primary treatment. Cochrane Database Syst Rev 2014; (9):CD006119. 
38. Geurts SM, de Vegt F, van Altena AM et al. Considering early detection of relapsed ovarian cancer: a review of the literature. Int J Gynecol Cancer 2011; 21(5): 837-845.

39. Geurts SM, de Vegt F, van Altena AM et al. Impact of routine follow-up examinations on life expectancy in ovarian cancer patients: a simulation study. Int J Gynecol Cancer 2012; 22(7): 1150-1157.

40. Geurts SM, van Altena AM, de Vegt F et al. No supportive evidence for clinical benefit of routine follow-up in ovarian cancer: a Dutch multicenter study. Int J Gynecol Cancer 2011; 21(4): 647-653.

41. Rustin GJ, van der Burg ME, on behalf of MRC and EORTC collaborators. A randomized trial in ovarian cancer (OC) of early treatment of relapse based on CA125 level alone versus delayed treatment based on conventional clinical indicators (MRC OV05/EORTC 55955 trials). J Clin Oncol (Meeting Abstracts) 2009; 27(18s): 1

42. Pujade-Lauraine $\mathrm{E}^{1}$, Ledermann $\mathrm{JA}^{2}$, Selle $\mathrm{F}^{3}$, Gebski $\mathrm{V}^{4}$, Penson $\mathrm{RT}^{5}$, Oza $\mathrm{AM}^{6}$, Korach $\mathrm{J}^{7}$, Huzarski $\mathrm{T}^{8}$, Poveda $\mathrm{A}^{9}$, Pignata $\mathrm{S}^{10}$, Friedlander $\mathrm{M}^{11}$, Colombo $\mathrm{N}^{12}$, Harter $\mathrm{P}^{13}$, Fujiwara $\mathrm{K}^{14}$, Ray-Coquard I ${ }^{15}$, Banerjee $\mathrm{S}^{16}$, Liu J ${ }^{17}$, Lowe $\mathrm{ES}^{18}$, Bloomfield $\mathrm{R}^{19}$, Pautier P20; SOLO2/ENGOT-Ov21 investigators. Olaparib tablets as maintenance therapy in patients with platinum-sensitive, relapsed ovarian cancer and a BRCA1/2 mutation (SOLO2/ENGOT-Ov21): a double-blind, randomised, placebo-controlled, phase 3 trial. Lancet Oncol. 2017 Sep;18(9):1274-1284. doi: 10.1016/S1470-2045(17)30469-2. Epub 2017 Jul 25.

43. Cox a, Ellen Bull b, Jane Cockle-Hearne a, Wendy Knibb a, Claire Potter a, Sara Faithfull. Nurse led telephone follow-up in ovarian cancer: A psychosocial perspective. European Journal of Oncology Nursing 12 (2008) 412-417.

44. https://www.cancerresearchuk.org/health-professional/cancer-statistics/statisticsby-cancer-type/vulval-cancer. Accessed December 2019

45. RCOG. Guidelines for the Diagnosis and Management of Vulval Carcinoma. https://www.rcog.org.uk/en/guidelinesresearchservices/guidelines/vulvalcarcinoma-guidelines-for-the-diagnosisand-managementof/ (2014). Accessed December 2019

46. Gonzalez Bosquet J11, Magrina JF, Gaffey TA, Hernandez JL, Webb MJ, Cliby WA, Podratz KC. Long-term survival and disease recurrence in patients with primary squamous cell carcinoma of the vulva. Gynecol Oncol. 2005 Jun;97(3):828-33. 
